\title{
Major Effects of Alkalinity on the Relationship Between Metabolism and Dissolved Inorganic Carbon Dynamics in Lakes
}

\author{
Hares Khan, ${ }^{1,2 *} \odot$ Alo Laas, ${ }^{2} \odot$ Rafael Marcé,,${ }^{3,4} \odot$ and Biel Obrador ${ }^{1} \odot$
}

\begin{abstract}
${ }^{1}$ Department of Evolutionary Biology, Ecology and Environmental Sciences, Institut de Recerca de la Biodiversitat (IRBio), University of Barcelona, Barcelona, Spain; ${ }^{2}$ Centre for Limnology, Institute of Agricultural and Environmental Sciences, Estonian University of Life Sciences, Tartu, Estonia; ${ }^{3}$ Catalan Institute for Water Research, ICRA, Girona, Spain; ${ }^{4}$ Universitat de Girona, Girona, Spain
\end{abstract}

\begin{abstract}
Several findings suggest that $\mathrm{CO}_{2}$ emissions in lakes are not always directly linked to changes in metabolism but can be associated with interactions with the dissolved inorganic carbon equilibrium. Alkalinity has been described as a determining factor in regulating the relative contributions of biological and inorganic processes to carbon dynamics in lakes. Here we analyzed the relationship between metabolic changes in dissolved oxygen (DO) and dissolved inorganic carbon (DIC) at different timescales in eight lakes covering a wide range in alkalinity. We used high-frequency data from automatic monitoring stations to explore the sensitivity of DIC to metabolic changes inferred from oxygen. To overcome the problem of noisy data, commonly found in high-frequency measurements datasets, we used Singular Spectrum Analysis to enhance the diel signal-to-noise ratio. Our results suggest that in most of the studied lakes, a large part of the measured variability in DO and DIC
\end{abstract}

Received 10 April 2019; accepted 22 January 2020;

published online 5 February 2020

Electronic supplementary material: The online version of this article (https://doi.org/10.1007/s10021-020-00488-6) contains supplementary material, which is available to authorized users.

Author Contributions BO, RM and AL conceived this study, AL collected the data, HK analyzed the data with support of all authors and wrote the first versions of the manuscript with inputs and edits by all others.

*Corresponding author; e-mail: hkhan.ch@gmail.com reflects non-metabolic processes. Furthermore, at low alkalinity, DIC dynamics appear to be mostly driven by aquatic metabolism, but this relationship weakens with increasing alkalinity. The observed deviations from the metabolic 1:1 stoichiometry between DO and DIC were strongly correlated with the deviations expected to occur from calcite precipitation, with a stronger correlation when accounting also for the benthic contribution of calcite precipitation. This highlights the role of calcite precipitation as an important driver of $\mathrm{CO}_{2}$ supersaturation in lakes with alkalinity above 1 meq $\mathrm{L}^{-1}$, which represents $57 \%$ of the global area of lakes and reservoirs around the world.

Key words: Carbon dynamics; Calcite precipitation; Metabolism; Alkalinity; Dissolved inorganic carbon; High-frequency measurements; Singular spectrum analysis; Cross-wavelets analysis.

\section{HighLIGHTS}

- Calcite precipitation is a major driver of carbon dynamics in lakes with alkalinity above 1 meq $\mathrm{L}^{-1}$.

- At low alkalinity, metabolism is the main driver of carbon dynamics. 


\section{INTRODUCTION}

Considering that lakes occupy a relatively small area in the global landscape, they are disproportionally active sites for carbon cycling due to their important roles in carbon transport, transformation and storage (Cole and others 2007; Battin and others 2009; Tranvik and others 2009). Globally, most lakes are supersaturated in $\mathrm{CO}_{2}$ and act as carbon sources to the atmosphere (Sobek and others 2005). The carbon emitted by these ecosystems is relevant and comparable in magnitude to global terrestrial net ecosystem production (Tranvik and others 2009). The $\mathrm{CO}_{2}$ emissions from lakes have widely been attributed to their heterotrophic activity that oxidizes terrestrially produced carbon (Del Giorgio and others 1999; Jonsson and others 2003; Duarte and Prairie 2005; Roehm and others 2009; Larsen and others 2011). Many studies that directly link $\mathrm{CO}_{2}$ supersaturation to net heterotrophy are conducted in lakes that have relatively low alkalinity and high dissolved organic carbon (DOC) values. Although this paradigm is often valid for such systems, it has recently been rejected for lakes and reservoirs of higher alkalinity. A study that relates $\mathrm{CO}_{2}$ emissions to lake metabolism in nineteen lakes of higher alkalinity shows that despite a positive relationship between $\mathrm{CO}_{2}$ emissions and respiration of organic matter, $\mathrm{CO}_{2}$ emissions often exceed the rates expected from lake metabolism (Sand-jensen and Staehr 2009). Several findings suggest that in such systems, major drivers of carbon dynamics include direct exogenous dissolved inorganic carbon (DIC) inputs from soil respiration and mineral weathering of the catchment, interactions with the DIC equilibrium, and calcite precipitation (Maberly and others 2012; McDonald and others 2013; Marcé and others 2015; Weyhenmeyer and others 2015; Wilkinson and others 2016).

The chemical equilibrium between photosynthesis and respiration implies a balance between inorganic carbon variability and net ecosystem production (NEP), whereby $1 \mathrm{~mol}$ of $\mathrm{O}_{2}$ respired produces $1 \mathrm{~mol}$ of DIC, and inversely, $1 \mathrm{~mol}$ of DIC is photosynthesized into $1 \mathrm{~mol}$ of $\mathrm{O}_{2}$ (Stumm and Morgan 1996). Imbalances between inorganic carbon variability and metabolic rates resulting in deviations from the one to one stoichiometry between dissolved oxygen (DO) and DIC in lakes are widely reported in the literature (Stets and others 2009; López and others 2011; McDonald and others 2013; Peeters and others 2016; Perga and others 2016). Such imbalances have in some cases reached a point where lakes are simultaneously in an autotrophic state, yet they emit $\mathrm{CO}_{2}$ to the atmosphere (Stets and others 2009; Marcé and others 2015; Peeters and others 2016; Perga and others 2016). According to a recent model, this could be the case for approximately $35 \%$ of the lakes and reservoirs in the contiguous United States (McDonald and others 2013). Hydrologic inputs and $\mathrm{CO}_{2}$ released by calcite precipitation are likely to be the main factors driving $\mathrm{CO}_{2}$ emissions in such lakes (Stets and others 2009; McDonald and others 2013; Marcé and others 2015; Perga and others 2016). A recent study shows that the sensitivity of $\mathrm{CO}_{2}$ supersaturation to DO disequilibrium weakens with increasing alkalinity and that above an alkalinity threshold of 1 meq $\mathrm{L}^{-1}$ it is possible to find lakes that are simultaneously supersaturated in $\mathrm{CO}_{2}$ and DO (Marcé and others 2015). This implies that above this alkalinity threshold $\mathrm{CO}_{2}$ supersaturation in lakes is directly regulated by DIC inputs from carbonate weathering and calcite precipitation and that this is a widespread phenomenon since $57 \%$ and $34 \%$ of the global area occupied by lakes and reservoirs have alkalinity values above 1 and 2 meq $\mathrm{L}^{-1}$, respectively (Marcé and others 2015).

In such lakes, summer DIC depletion due to photosynthesis comes largely at the expense of alkalinity, with only minimal changes in $\mathrm{pCO}_{2}$ and $\mathrm{pH}$ (Mcconnaughey and others 1994). An explanation lies in the biogenic process of calcite precipitation that is enhanced during summer stratification, when algal blooms increase $\mathrm{pH}$ through photosynthesis and offer abundant nucleation sites around the surface of micro-algae (Müller and others 2016). Summer calcification reduces alkalinity and calcium levels, generating an equal molar quantity of $\mathrm{CO}_{2}$, thereby compensating photosynthetic $\mathrm{CO}_{2}$ depletion and maintaining $\mathrm{CO}_{2}$ partial pressure $\left(\mathrm{pCO}_{2}\right)$ values within bounds that sustain primary production (Mcconnaughey and others 1994; Andersen and others 2019). This mechanism is less relevant in lakes of low alkalinity where calcite precipitation is unlikely to occur at high rates and therefore primary production is potentially carbon limited because of the lack of inorganically produced $\mathrm{CO}_{2}$ (Kragh and SandJensen 2018). The mass balance equation of calcite precipitation implies the release of $1 \mathrm{~mol}$ of $\mathrm{CO}_{2}$, yet it results in a net loss of $1 \mathrm{~mol}$ of DIC and two equivalents of total alkalinity (TA):

$$
\begin{aligned}
\mathrm{Ca}^{2+}+2 \mathrm{HCO}_{3}^{-} \rightarrow & \mathrm{CaCO}_{3}+\mathrm{CO}_{2} \\
& +\mathrm{H}_{2} \mathrm{O}(\Delta \mathrm{TA}=-2 \mathrm{eq})
\end{aligned}
$$


A recent study on a lake of relatively high alkalinity (4.5 meq $\mathrm{L}^{-1}$ ) shows that about $40-70 \%$ of sediment organic carbon originates from alkalinity export from the catchment, suggesting that primary producers actively take up DIC of terrestrial origin, promoting calcite precipitation and turning such lakes into "alkalinity sinks" during summer (Nõges and others 2016). Despite acting as an alkalinity sink, it is widely acknowledged that calcification promotes $\mathrm{CO}_{2}$ supersaturation of surface waters by releasing $\mathrm{CO}_{2}$ (Opdyke and Walker 1992; Gattuso and others 1993, 1996, 1999; Frankignoulle and others 1994, 1995; Suzuki 1998). Therefore, summer calcification could be an explanation for the deviation from the 1:1 stoichiometry between DO and DIC variability commonly found in lakes of high alkalinity. However, other processes could result in such deviations, such as anaerobic respiration (Stumm and Morgan 1996; Torgersen and Branco 2007; Wissel and others 2008), physical processes such as gas exchanges with the atmosphere (Wissel and others 2008) or horizontal and vertical gas exchanges with nearshore or deeper waters (Antenucci and others 2013), as well as direct DIC inputs caused by storm events (Vachon and del Giorgio 2014). While the importance of calcite precipitation in $\mathrm{CO}_{2}$ levels and emissions is well documented in marine systems, it is yet to be recognized as an important component of the carbon cycle in freshwater systems.

The objective of this research is to assess the sensitivity of DIC variability to metabolic changes in DO along a gradient of alkalinity. For this, we use high-frequency data of dissolved oxygen, $\mathrm{pCO}_{2}, \mathrm{pH}$ and temperature from lakes covering a wide range in alkalinity. A theoretical model that accounts for the effect of calcite precipitation on the DO-DIC relationship is used as a comparison to the empirical data to highlight the importance of this process as a driver of carbon dynamics in lakes. The overarching aim of this study is thus to determine the main drivers of DIC dynamics along an alkalinity gradient. Our hypothesis is that lake metabolism is the main driver of carbon dynamics in lakes of low alkalinity but that with increasing alkalinity the importance of this driver becomes relatively low compared to other processes such as calcite precipitation.

\section{MethodS}

\section{Study Sites}

The data for this study were collected from eight Estonian lakes during the summer period from July to September in 2014 and are available in open access (Laas and Khan 2019). The studied lakes include Lake Peipsi, Võrtsjärv, Saadjärv, Lake Ülemiste, Mullutu Suurlaht, Lake Erastvere, Äntu Sinijärv and Valguta Mustjärv (Table 1). Based on their area, conductivity, thermal stratification, alkalinity, chloride content and color, each of these lakes belongs to different lake types (Ministry of the Environment 2009) according to the European Water Framework Directive (European Union 2000). Total alkalinity ranges from 0.5 to 4.8 meq $\mathrm{L}^{-1}$. The lakes also cover a variety of trophic states, ranging from mesotrophic to hypertrophic states according to the OECD trophic state classification (Caspers 1984). In addition, they differ substantially in their water retention time as well as in their catchment characteristics, especially in regard to land use. Each of these lakes has been described in detail in previous studies (Rõõm and others 2014; Cremona and others 2016; Laas and others 2016).

\section{Monitoring Stations and Measured Parameters}

All lakes were continuously monitored between 6 and 12 full days using a high-frequency measurement platform or a small lake buoy (OMC-7012 data-buoy). In most lakes, the automated stations were installed near the deepest point, except in lake Peipsi, where it was placed in Mustvee bay, approximately $1 \mathrm{~km}$ from the western shore because of security reasons. A multi-parametric sonde (Yellow Springs Instruments 6600 V2-4) was used for continuous measurements of DO concentration, $\mathrm{pH}$ and water temperature at 0.5 or $1-\mathrm{m}$ depth in all lakes. The multi-parametric sonde was equipped with an in-built cleaning system for optical DO sensor, whereas other sensors were manually cleaned on a weekly basis. Dissolved $\mathrm{CO}_{2}$ was measured at 0.5 or $1-\mathrm{m}$ depth using membranecovered optical $\mathrm{CO}_{2}$ sensors (AMT Analysenmesstechnik $\mathrm{GmbH}$ ) with measuring ranges of $30 \mathrm{mg} \mathrm{L}^{-1}$ and $80 \mathrm{mg} \mathrm{L}^{-1}$. Measured water temperature and air pressure data were used to calculate the real $\mathrm{pCO}_{2}$ and dissolved $\mathrm{CO}_{2}$ concentration from the signals captured from the sensor, according to manufacturer manuals (Laas and others 2016). A calibration of all sensors was performed before and after the deployment. For data collection and storage, all platforms were equipped with OMC-045-II GPRS data loggers. Sensors were automatically measuring at a time interval of 10 or 30 min depending on power availability. 


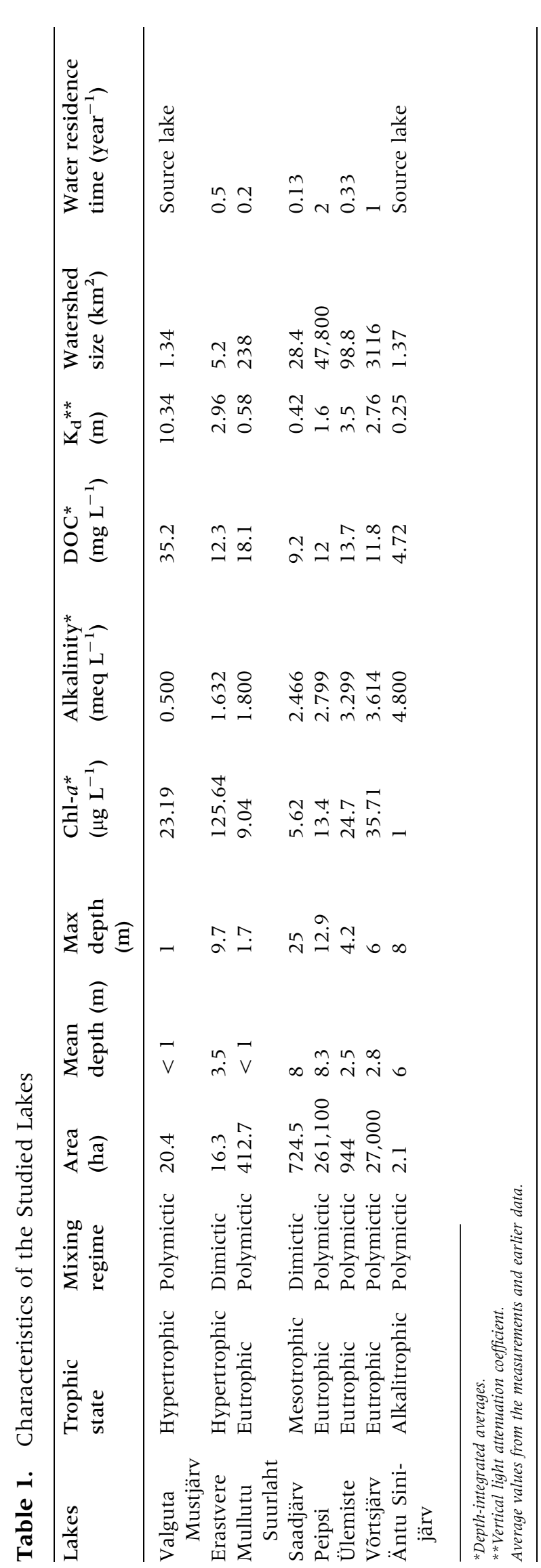

\section{Data Analysis}

For each lake, an alkalinity value for each time step was calculated using $\mathrm{pCO}_{2}$ and $\mathrm{pH}$ as input parameters for the $\mathrm{CO}_{2}$ sys program (Lewis and others 1998) following Millero (1979). These were then averaged to obtain the mean alkalinity value for each lake and sampling period. Dissolved inorganic carbon (DIC) was calculated for each time step using $\mathrm{pH}$ and the average alkalinity as input parameters in $\mathrm{CO}_{2}$ sys. Alkalinity had to be averaged to avoid unrealistic DIC values due to the large errors in alkalinity propagated by the limited precision of the field $\mathrm{pH}$ sensors (typically $\sim 0.2 \mathrm{pH}$ units). Using average alkalinity and $\mathrm{pH}$ as inputs resulted in cleaner and more realistic DIC values compared to other alternatives of calculating DIC (for example, using $\mathrm{CO}_{2}$ and $\mathrm{pH}$ as inputs).

After obtaining the DIC time series, the next step was to identify the presence of a 24 -h metabolic signal for DO and DIC. This was done by performing a continuous wavelet-based analysis using the R (R Development Core Team 2015) "biwavelet" package (Gouhier and others 2015). Wavelets can be used to identify time-dependent structures in time series, in this case the diel metabolic pattern known to occur for DO and DIC concentrations (Hanson and others 2006) (see supplementary material). As a support to the wavelet analysis, periodograms for DO and DIC concentrations were made using the time series analysis "TSA" package in R (Chan and Ripley 2018). Periodograms offer a more general view of the main time-dependent structures within an entire time series.

Then we assessed how DIC variability relates to DO variability by testing the sensitivity of DIC to changes in DO. Bivariate wavelets were used to identify common time periods at which DO and DIC oscillate, and how these common periods evolve during the entire length of the time series. Besides indicating common oscillations between two time series, cross-wavelets also examine whether there is a consistent phase relationship between the series, which is suggestive of causality between the two time series (Grinsted and others 2004) (see supplementary material). In the case of common oscillations between DO and DIC, one would expect an anti-phase relationship because the metabolic reaction implies that an increase in one leads to a decrease in the other, and vice versa. Because of the large amount of noise and random signals that are not related to the metabolic diel signal, we decided to enhance the signal-to-noise ratio by isolating the 24-h-frequency oscillations of DO and DIC from all other signals. To do so, we 
used the Singular Spectrum Analysis "SSA" R package (Zhao 2016). SSA is a tool that allows identifying and extracting fundamental oscillatory components from an original time series (see supplementary material). The $\mathrm{R}$ code that was used in this analysis is published and freely available (Khan 2019). Once the 24-h diel cycle components were identified, they were grouped and reconstructed into a new time series following Golyandina and Korobeynikov (2014). This method efficiently isolates the diel seasonal signal from a time series, even if it is weak or if the time series is noisy (see supplementary Figures S5 and S6 for comparison of a diel signal extracted from a clean versus noisy time series). For lake Äntu Sinijärv, the diel signal in DIC was very weak and had to be extracted by performing a Multivariate Singular Spectrum Analysis (MSSA) using the isolated diel signal of DO and the original time series of DIC as inputs. DIC and DO rates of change (dDO/dt and $\mathrm{dDIC} / \mathrm{dt}$ ) were calculated from the signal enhanced series and expressed in $\mu \mathrm{mol} \mathrm{L}{ }^{-1} \mathrm{~min}^{-1}$. Therefore, corrections for air-water gas exchanges are not necessary because the rates are calculated from isolated metabolic signals that have been removed from the effect of any non-metabolic process, including airwater gas exchanges.

Linear regressions were used to test the effect of $\mathrm{dDO} / \mathrm{dt}$ on $\mathrm{dDIC} / \mathrm{dt}$ in all lakes. Although all these relationships were highly significant, the main parameter of interest was the slope of the relationship. A theoretical slope of about -1 is expected from the stoichiometry of aerobic respiration and photosynthesis (Stumm and Morgan 1996; Torgersen and Branco 2007). The slope of -1 is an estimation that can be applied only in aerobic conditions without anaerobic respiration or other processes that can affect DIC concentrations such as calcite precipitation or direct DIC inputs following a storm event (Stumm and Morgan 1996; Vachon and del Giorgio 2014). All measurements were taken from surface waters where the effect of anaerobic respiration on DIC concentrations is not relevant according to the depth distributions of temperature, $\mathrm{DO}$ and $\mathrm{CO}_{2}$ reported for each lake during the same period of measurements in a previous study (Laas and others 2016). However, calcite precipitation could influence DIC concentrations in these lakes. Therefore, deviations from the theoretical -1 metabolic slope were interpreted with a focus on calcite precipitation.

The final step was to assess how alkalinity affects the sensitivity of DIC to metabolism. To do so, the slopes of the linear regression models were plotted against the alkalinity for all studied lakes. We compared the empirical slopes with the theoretical slopes under the presence of reactions with calcite. For each lake, we calculated a theoretical time series of $\mathrm{dDIC} / \mathrm{dt}$ that accounts for the effect of precipitation and dissolution of carbonates on $\mathrm{dDIC/dt}$ following a simple model:

$$
\mathrm{dDIC} / \mathrm{dt}_{\text {theoretical }}=-\mathrm{dDO} / \mathrm{dt}-\alpha \mathrm{dDO} / \mathrm{dt}
$$

where $\alpha$ is the molar ratio between precipitation and dissolution of carbonates and NEP (McConnaughey and Whelan 1997). The values of $\alpha$ were calculated according to three different hypotheses (Table 2). The first hypothesis assumes that $\alpha=0$ which corresponds to a system with no calcite precipitation, that is, where all changes in DIC are explained by aerobic metabolism. The second hypothesis assumes an alkalinity-dependent value for $\alpha$, using the same values as suggested in Marcé and others (2015), whereby $\alpha=0$ at alkalinity below 1 meq $\mathrm{L}^{-1}$ (McConnaughey and Whelan 1997), $\alpha=0.2$ at alkalinity between 1 and $2.23 \mathrm{meq} \mathrm{L}^{-1}$, and $\alpha=0.6$ at alkalinity above 2.23 meq $\mathrm{L}^{-1}$. The third hypothesis assumes these same alkalinity-dependent values for $\alpha$ with an additional correction for the benthic fraction (BF) of total primary production in the lakes. By doing this correction, the $\alpha$ parameter is able to account for pelagic calcite precipitation as well as benthic calcification by calcifying macrophytes. To do this, we used the percentage of benthic primary production of each lake obtained from a previous study on these same lakes that was conducted during the same period of study as the data used here (Cremona and others 2016). We assumed benthic production to be composed of calcifying macrophytes, based on previous studies of these eight lakes (Cremona and others 2016; Laas and others 2016). An approximate 1:1 calcification to photosynthesis ratio in such organisms has been reported (McConnaughey 1991; Mcconnaughey and others 1994; McConnaughey and Whelan 1997). Therefore, we attributed an $\alpha$ value of 1 to the benthic production and corrected the $\alpha$ values from Marcé and others (2015) according to the ratio between pelagic primary production and benthic primary production.

At this point, one must remember that the observed dDIC/dt values come from DIC values that were calculated using a constant average alkalinity. Although the diurnal changes in alkalinity are too small to be accurately estimated by using $\mathrm{CO}_{2}$ and $\mathrm{pH}$ coming from field probes, assuming a constant alkalinity value tends to underestimate the changes in DIC, as it omits changes in the chemical equi- 


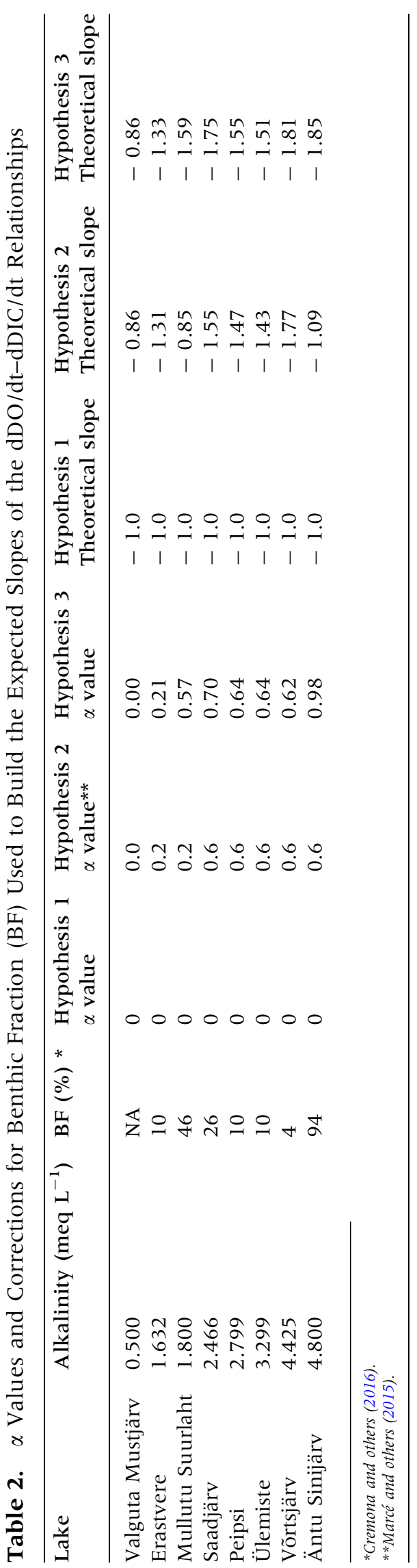

librium of the carbonate system. To overcome this limitation, we calculated a corrected observed $\mathrm{dDIC/dt}$ that accounts for calcite reactions:

$$
\mathrm{dDIC} / \mathrm{dt}_{\text {corrected }}=\mathrm{dDIC} / \mathrm{dt}-\alpha 2 \mathrm{dDIC} / \mathrm{dt}
$$

where $\alpha$ is the calcification parameter in equation 2. This procedure is thus generating a corrected observed $\mathrm{dDIC} / \mathrm{dt}$ dataset (and thus an observed slope between $\mathrm{dDIC} / \mathrm{dt}$ and $\mathrm{dDO} / \mathrm{dt}$ ) which is dependent on the three hypotheses used for assigning values to $\alpha$. Note that for Hypothesis 1 $\alpha$ equals 0 and $\mathrm{dDIC} / \mathrm{dt}_{\text {corrected }}$ equals $\mathrm{dDIC} / \mathrm{dt}$. The slopes $\mathrm{dDIC} / \mathrm{dt}_{\text {corrected }}$ versus $\mathrm{dDO} / \mathrm{dt}$ and $\mathrm{dDIC} /$ $\mathrm{dt}_{\text {theoretical }}$ versus $\mathrm{dDO} / \mathrm{dt}$ were calculated using linear regression and compared by plotting them along the alkalinity gradient. The rationale of the analysis is that the theoretical slopes and the observed slopes (using $\mathrm{dDIC} / \mathrm{dt}_{\text {corrected }}$ ) will agree only in the case of using the appropriate hypothesis for the calcite reactions $(\alpha)$.

\section{Results}

Presence and Strength of Metabolic Signals in DO and DIC Dynamics

The presence of a metabolic signal was assessed using periodograms which estimate the spectral density of a time series and shows what are the dominating frequencies of oscillation composing it. The dominating spikes at $24-\mathrm{h}$ frequency indicate a clear diel metabolic signal (24-h pattern) for DO and DIC in most lakes, except in Äntu Sinijärv, Saadjärv and lake Ülemiste where the diel signals are weak resulting in a shorter spike at the 24-hfrequency mark (Figures 1 and 2). The periodograms showed an important number of signals at other frequencies that did not correspond to the metabolic diel pattern. While the spectral density of these non-metabolic signals was relatively low, their relevance was amplified when using rates of change $(\mathrm{dDO} / \mathrm{dt}$ and $\mathrm{dDIC} / \mathrm{dt})$ rather than raw concentrations, especially the noisy signals at short frequencies (see Supplementary Figures S1 and S2).

\section{Relationship Between DIC and DO Variability}

Cross-wavelets were used to identify at what time period synchronized oscillations can be found between DO and DIC and the phase of these synchronizations. Due to the metabolic stoichiometry between DO and DIC, an anti-phase synchronization between both variables is to be expected at the 

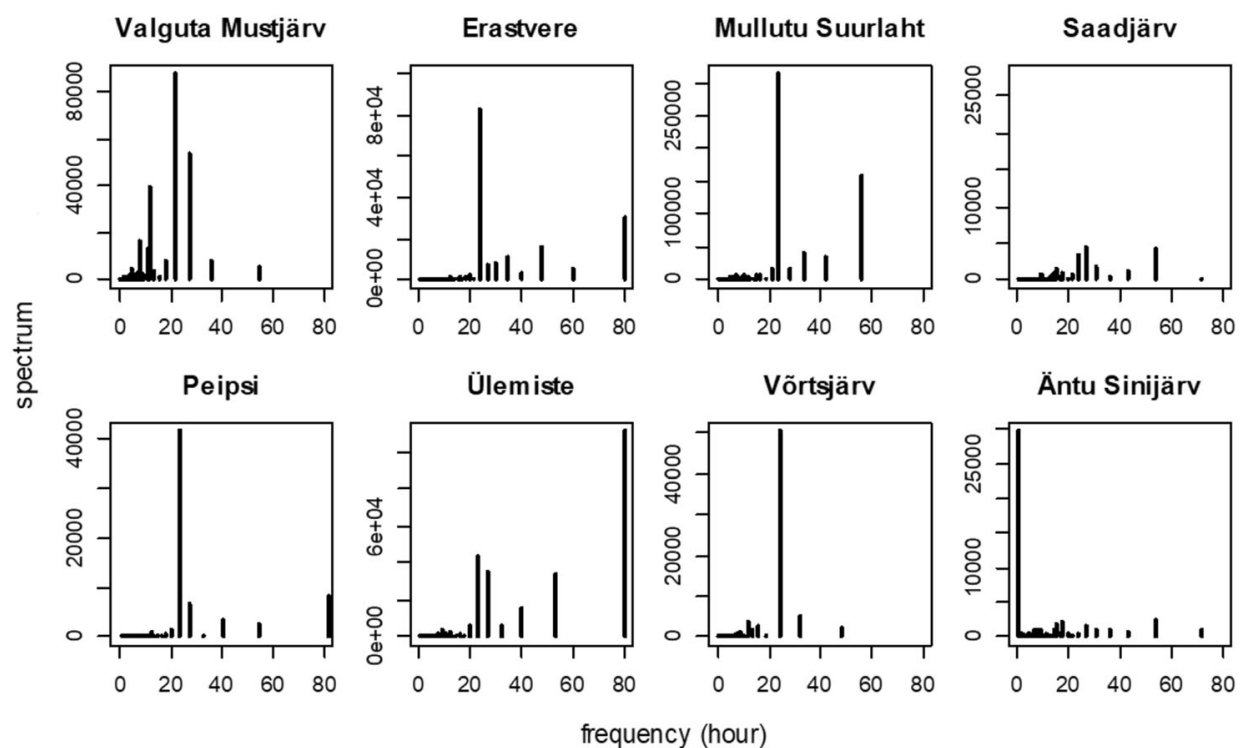

Figure 1. Periodograms for dissolved oxygen (DO) in the studied lakes. The $x$-axis corresponds to the frequency of oscillation (hours) at which the spectral density is estimated. The $y$-axis corresponds to the spectral density or power spectrum, with higher values indicating important features of the signal at a given frequency. Notice the dominating spikes at 24 -h frequency.
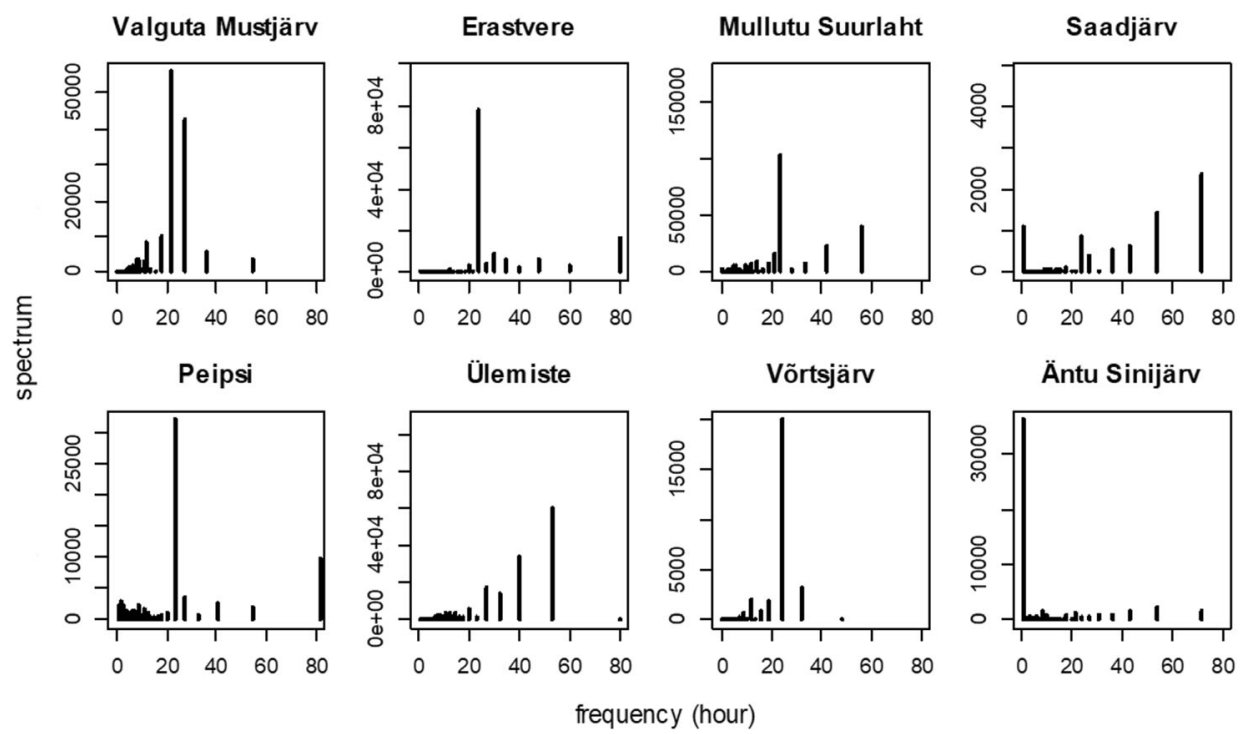

Figure 2. Periodograms for dissolved inorganic carbon (DIC) in the studied lakes. The $x$-axis corresponds to the frequency of oscillation (hours) at which the spectral density is estimated ( $y$-axis). The $y$-axis corresponds to the spectral density or power spectrum, with higher values indicating important features of the signal at a given frequency. Notice the dominating spikes at 24 -h frequency.

24-h frequency, whereby an increase in DO results in a decrease in DIC, and vice versa. This was apparent for most of the lakes in the cross-wavelets, where a "cloud" of arrows pointing to the left indicate a relatively strong anti-phase synchronization around the 24-h period (Figure 3). Although this diel synchronization in oscillation was relatively strong in some lakes (Valguta Mustjärv,
Erastvere, Mullutu Suurlaht, Peipsi and Võrtsjärv), it was weak in others (Saadjärv, Ülemiste and Äntu Sinijärv), causing disruptions in the synchronicity between DO and DIC along the time series (Figure 3). The lack of coupling was most obvious in lake Äntu Sinijärv. All lakes showed a relatively important amount of significant coupling in oscillation at time periods shorter than $24 \mathrm{~h}$ (Figure 3). 

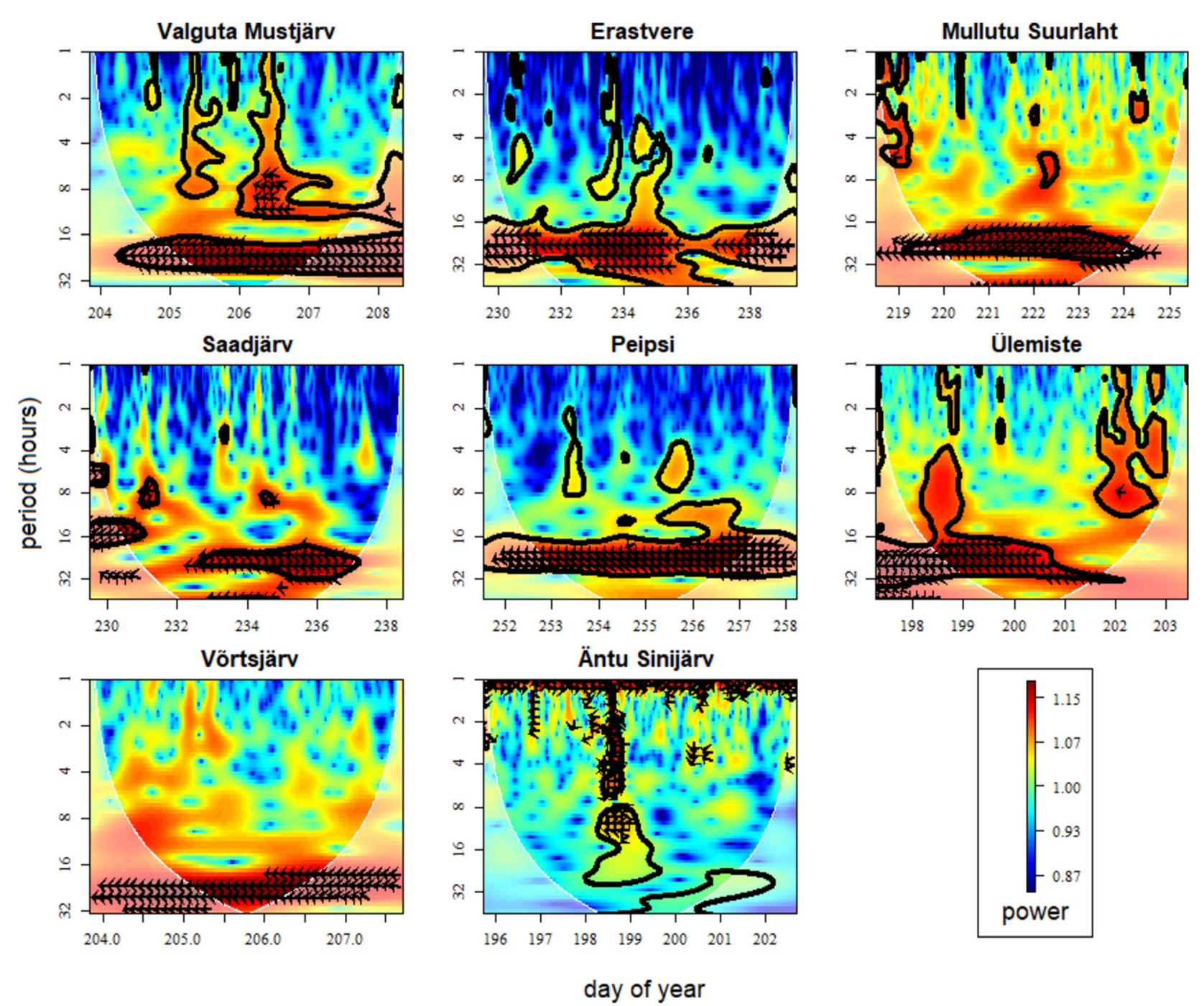

Figure 3. Cross-wavelets between DO and DIC for each lake, showing regions in the time-frequency space with common power. The power bar represents the amplitude-squared of signals, with higher values corresponding to important features of the signal. The $x$-axis represents the time (expressed as day of the year) and allows to see the evolution of common oscillatory patterns between DO and DIC in time. The $y$-axis represents the period of oscillation (in hours). Significant synchronizations in oscillations between DO and DIC at a certain period are delimited by the black contours. Arrows pointing to the left symbolize an anti-phase relationship. Notice the dominance of a synchronized anti-phase pattern around 24-h frequency in most lakes.

These common oscillations ranged from time periods of less than $1 \mathrm{~h}$ up to several hours and could be caused by water movements caused by convection, minor mixing events or seiches, as well as noise resulting from the sensitivity thresholds of the sensors.

The presence of non-metabolic signals in DO and DIC that were oscillating at other frequencies than the metabolic 24-h frequency resulted in poor relationships between $\mathrm{dDO} / \mathrm{dt}$ and $\mathrm{dDIC} / \mathrm{dt}$ (Supplementary Figure S3). However, using the isolated metabolic diel signals to calculate $\mathrm{dDO} / \mathrm{dt}$ and $\mathrm{dDIC/dt}$ (Supplementary Figure S4) resulted in much stronger relationships between the two (Figure 4). These relationships were significant for all lakes, with substantial differences in slope between lakes.

In most of the lakes, the slopes of these relationships were close to the ones found by performing linear regression models on $\mathrm{dDO} / \mathrm{dt}$ and $\mathrm{dDIC/dt}$ obtained from the raw data, yet the $R^{2}$ values dramatically increased (Table 3 ). However, the slope for this relationship in Saadjärv turned from positive to negative. Considering the low $R^{2}$ value $(0.05)$ of the relationship using the raw data and its high increase $\left(R^{2}=0.91\right)$ when using the 

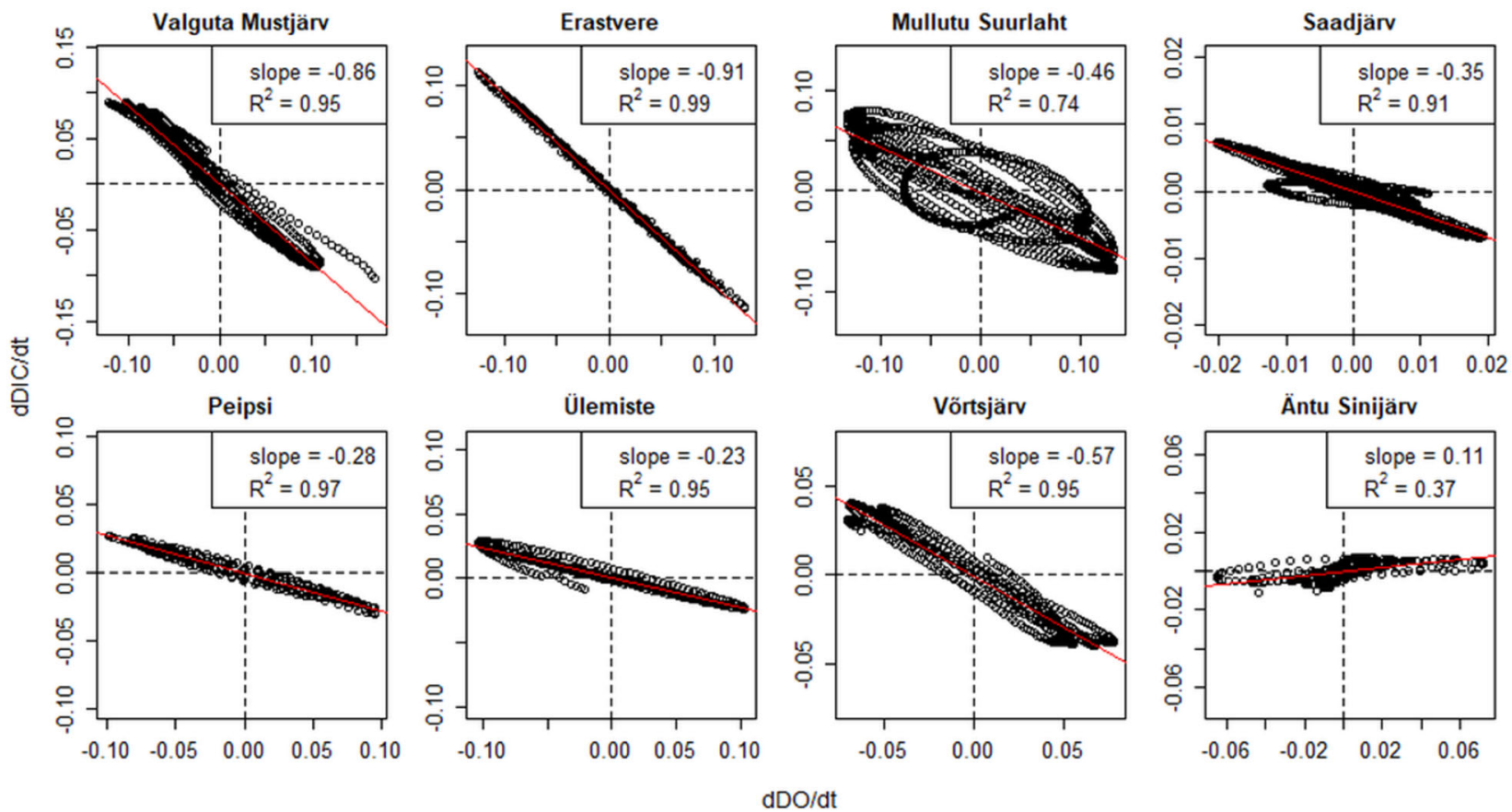

Figure 4. Relationship between rates of change in DO (dDO/dt) calculated from the isolated diel signal of DO, and rates of change in DIC (dDIC/dt) calculated from the isolated diel signal in DIC. All relationships are significant $(p<0.001)$, with the slope and $R^{2}$ values indicated in the top-right window of each plot. The lakes are ordered from low to high alkalinity (top left to bottom right).

Table 3. Results of Linear Regression Models Testing the Effect of $\mathrm{dDO} / \mathrm{dt}$ on $\mathrm{dDIC} / \mathrm{dt}$ Using the Raw Data (left) and the Isolated 24-h Signal Data (right)

Linear models using raw data

Linear models using isolated diel signal data

\begin{tabular}{|c|c|c|c|c|c|c|c|}
\hline Lake & Alkalinity & Slope & $p$ value slope $(* *<0.001)$ & $R^{2}$ & Slope & $p$ value slope $(* *<0.001)$ & $R^{2}$ \\
\hline Valguta Mustjärv & 0.50 & -1.00 & $* *$ & 0.25 & -0.89 & $* *$ & 0.97 \\
\hline Erastvere & 1.63 & -0.91 & $* *$ & 0.92 & -0.91 & $* *$ & 1.00 \\
\hline Mullutu Suurlaht & 1.80 & -0.12 & $* *$ & 0.03 & -0.46 & $* *$ & 0.74 \\
\hline Saadjärv & 2.47 & 0.46 & ** & 0.05 & -0.35 & $* *$ & 0.91 \\
\hline Peipsi & 2.80 & -0.22 & $* *$ & 0.19 & -0.28 & $* *$ & 0.97 \\
\hline Ülemiste & 3.30 & -0.58 & $* *$ & 0.46 & -0.23 & $* *$ & 0.95 \\
\hline Võrtsjärv & 3.61 & -0.47 & $* *$ & 0.25 & -0.57 & $* *$ & 0.95 \\
\hline Äntu Sinijärv & 4.80 & 0.74 & $* *$ & 0.53 & 0.11 & $* *$ & 0.37 \\
\hline
\end{tabular}

diel data, we concluded that on a 24-hourly scale, the slope was indeed negative, which goes in line with the anti-phase relationship between DO and DIC expected from ecosystem metabolism.

\section{Effect of Alkalinity on the Sensitivity of DIC to Metabolism}

Finally, we wanted to know how alkalinity affects the sensitivity of DIC to metabolic changes in DO.
For this, we tested the three hypotheses using $\mathrm{dDIC} / \mathrm{dt}_{\text {theoretical }}$ (equation 2) to see whether metabolism is the only driver for changes in $\mathrm{dDIC} / \mathrm{dt}$ (Figure 5A), whether pelagic calcite precipitation plays a role (Figure 5B) or whether pelagic and benthic calcite precipitation both affect the sensitivity of DIC to metabolism (Figure 5C). The observed slopes did not fit the expected slope under the first hypothesis, equal to -1 in all lakes (Figure $5 \mathrm{~A}$ ). For the two last scenarios (Figure 5B and 

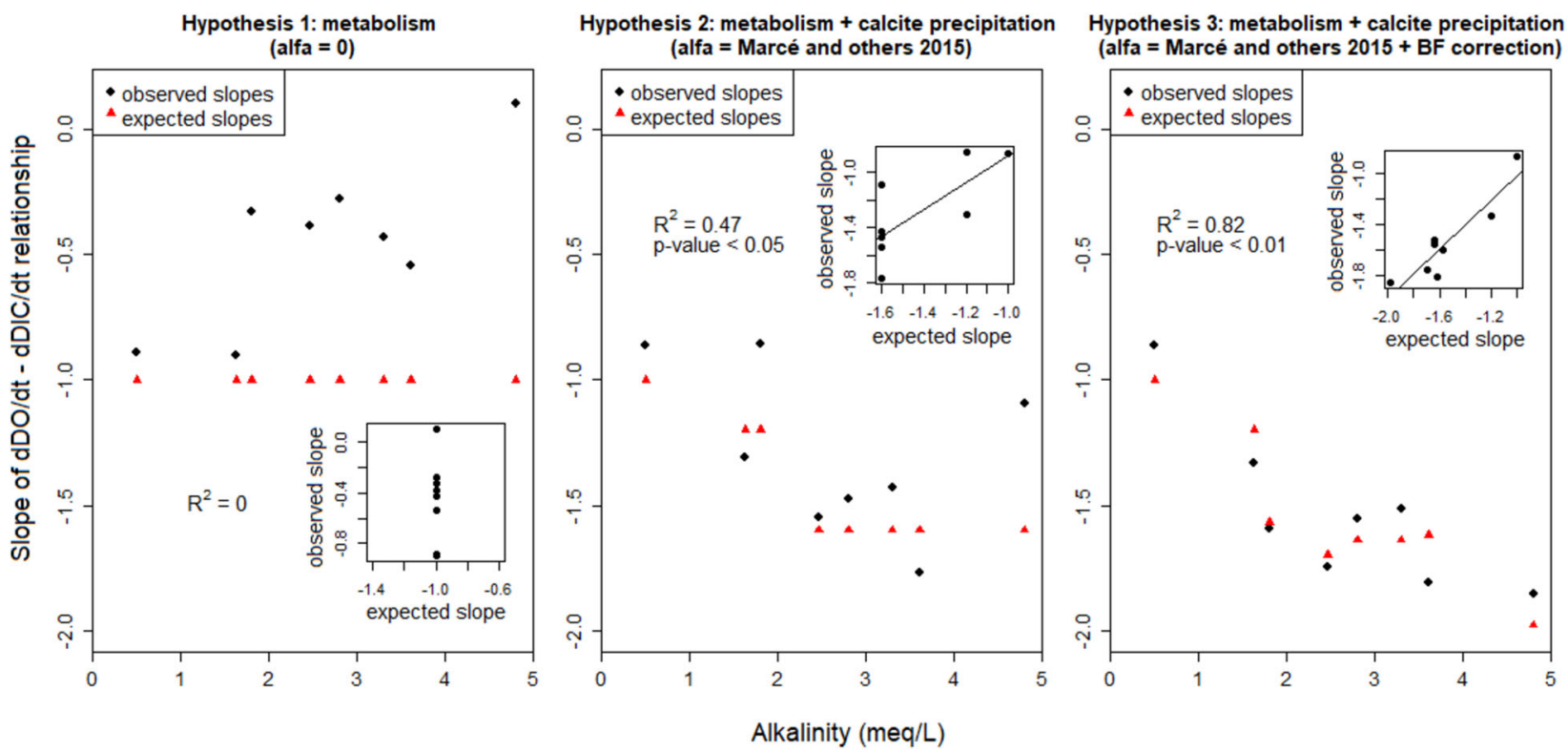

Figure 5. Effect of alkalinity on the sensitivity of dDIC/dt to changes in dDO/dt for each lake. Comparing the observed slopes (corrected using Eq. 3) of the $\mathrm{dDO} / \mathrm{dt}-\mathrm{dDIC} / \mathrm{dt}$ relationship with expected slopes (calculated using Eq. 2) for each lake based on three different hypotheses: A metabolism is the only factor controlling carbon dynamics $(\alpha=0)$, B the $\alpha$ parameter (as defined in Marcé and others 2015) is added to the metabolism equation to account for effects of pelagic calcite precipitation on carbon dynamics, $\mathbf{C}$ the value of $\alpha$ is corrected for each lake for its benthic fraction to account for the effect of pelagic calcite precipitation and benthic calcifying macrophytes.

C), the expected slopes of the $\mathrm{dDO} / \mathrm{dt}$ versus $\mathrm{dDIC/}$ $\mathrm{dt}$ relationships were very close to the observed ones, especially when using the correction for benthic metabolism (Hypothesis 3, Figure 5C). The relationship between observed and expected slopes had the highest $R^{2}$ value for the third hypothesis (Figure 5C).

\section{Discussion}

\section{Effects of Calcite Precipitation on the Relationship Between DO and DIC}

Comparing $\mathrm{dDO} / \mathrm{dt}$ with $\mathrm{dDIC} / \mathrm{dt}$ calculated from the isolated 24-h signals is a way to assess the relative importance of metabolism in controlling carbon dynamics. The stoichiometry of photosynthesis and respiration implies a 1:1 relationship between changes in DIC and DO whereby 1 mol of DO respired produces $1 \mathrm{~mol}$ of DIC, and inversely, $1 \mathrm{~mol}$ of DIC is photosynthesized into $1 \mathrm{~mol}$ of DO (Stumm and Morgan 1996). Due to this stoichiometry, it is expected that a slope close to -1 is found in the linear relationship between $\mathrm{dDO} / \mathrm{dt}$ with $\mathrm{dDIC/dt}$ if aerobic metabolism is the main driver of carbon dynamics (Stumm and Morgan 1996). Calcite precipitation/dissolution processes can involve deviations from the metabolic slope of -1 due to its release/consumption of $\mathrm{CO}_{2}$ (Barrón and others 2006; Gattuso and others 1999; Obrador and Pretus 2013). Such deviations can also be caused by anaerobic processes (Torgersen and Branco 2007) or can be correlated with major gradients of ecosystem level, substrate level, and bacterial community level characteristics (Berggren and others 2011).

Among the eight studied lakes, only two lakes, Erastvere and Valguta Mustjärv, showed a slope near -1 for the $\mathrm{dDO} / \mathrm{dt}-\mathrm{dDIC} / \mathrm{dt}$ relationship (Figure 4). This implies that changes in $\mathrm{dDIC/dt}$ are strongly negatively correlated, at an almost equal molar ratio, with metabolic changes in $\mathrm{dDO} / \mathrm{dt}$. These two lakes have the lowest alkalinity values (1.6 and 0.5 meq $L^{-1}$, respectively). In all other lakes of higher alkalinity, the slopes between $\mathrm{dDO} /$ $\mathrm{dt}$ and dDIC/dt decrease and gradually approach a value of 0 at higher alkalinity (Figure 5A), which involves a deviation from the metabolic 1:1 stoichiometry between changes in DO and DIC. This means that with increasing alkalinity, the importance of metabolism in driving changes in DIC diminishes, as highlighted by Marcé and others (2015). DIC dynamics in lakes of higher alkalinity can be also affected by chemically enhanced uptake of atmospheric $\mathrm{CO}_{2}$ (Kragh and Sand-Jensen 2018). However, our methods of isolating the metabolic diel signal eliminates any physical effects 
such as gas exchanges or water movements and therefore chemically enhanced uptake of atmospheric $\mathrm{CO}_{2}$ is unlikely to be the cause of the observed deviations from the metabolic $1: 1$ stoichiometry.

Because of the chemical stoichiometry of respiration and photosynthesis, our studied lakes had an anti-phase coupling between the diel signals of DO and DIC, but with deviations from the 1:1 stoichiometry at increasing alkalinity, suggesting that although the anti-phase is tightly linked to photosynthetic or respiratory processes, deviations from this are influenced by the carbonate equilibrium system. The most plausible explanation of this mechanism is calcite precipitation, as it is tightly linked to alkalinity and photosynthetic activity. High alkalinity lakes are likely to precipitate larger quantities of calcite due to the high content of bicarbonates and carbonates. Photosynthesis raises the $\mathrm{pH}$, influencing the carbonic acid equilibrium and shifting the balance toward oversaturation of carbonates (Minder-Zürich 1922; Dittrich and Obst 2004). Therefore, calcite precipitation has been reported to peak with high summer rates of primary production (Müller and others 2016). Additionally, picoplankton and cyanobacteria can act as nucleation sites for calcite precipitation (Stabel 1986; Dittrich and Obst 2004; Obst and others 2009). The relationship between primary production and calcite precipitation has rarely been quantified in freshwater systems. The few studies that do so have suggested that depending on the lake alkalinity, 1 mol of DIC consumed to produce $1 \mathrm{~mol}$ of $\mathrm{O}_{2}$ through photosynthesis induces between 0.2 and $1 \mathrm{~mol}$ of calcite precipitation (Megard 1968; Mcconnaughey and others 1994; McConnaughey and Whelan 1997) and that below an alkalinity threshold of 1 meq $\mathrm{L}^{-1}$, calcification is unlikely to occur (Marcé and others 2015). This range is consistent with the $\alpha$ values used in this study. A similar range is reported in marine planktonic assemblages (Riebesell and others 2000).

The chemical equation describing calcite precipitation implies that for each mole of calcite that precipitates, there is a loss of $1 \mathrm{~mol}$ of DIC and 2 mol of TA (equation 1). The combined effect of metabolism and calcite precipitation results in a net loss of -1 to -2 mol of DIC per mole of DO produced. However, the observed slopes of the $\mathrm{dDO} / \mathrm{dt}-\mathrm{dDIC} / \mathrm{dt}$ relationships in the 8 studied lakes ranged between -1 and 0.1 , which is inconsistent with the theoretical slope of -1 to -2 . This inconsistency can easily be explained by the methods used to calculate DIC. The high variability in alkalinity caused by the limited sensitivity of field $\mathrm{pH}$ sensors made it impossible to use diurnal changes in alkalinity. Instead, the alkalinity values were averaged and used in combination with $\mathrm{pH}$ to calculate DIC. Correcting dDIC/dt for theoretical changes in alkalinity (equation 3 ) results in slopes that are in the correct range between -1 and -2 . This highlights the importance of considering diurnal changes in alkalinity for correct estimations of DIC, something still challenging with current sensor technologies.

Here, we show that the slopes clearly deviated from the metabolic slope of -1 , especially at higher alkalinity (Figure 5A). Accounting for pelagic calcite precipitation showed a positive relationship $\left(R^{2}=0.47\right)$ between the observed slopes and the expected slopes (Figure 5B). However, in the case of two lakes, Mullutu Suurlaht and Äntu Sinijärv, the difference between observed and expected slope was still relatively high compared to the other lakes (Figure 5B, alkalinity 1.8 and $4.8 \mathrm{meq} \mathrm{L}^{-1}$, respectively). These two lakes share the common characteristics of being shallow and having a thick layer of calcifying macrophytes of the genus Chara at their bottom floor. An approximate $1: 1$ calcification to photosynthesis ratio $(\alpha=1)$ in such organisms has been reported (McConnaughey 1991; Mcconnaughey and others 1994; McConnaughey and Whelan 1997). This is due to their ability to use $\mathrm{HCO}_{3}$ - instead of $\mathrm{CO}_{2}$ for photosynthesis and due to an efficient coupling between carbon uptake at the acidic part of the cell surface and $\mathrm{CaCO}_{3}$ precipitation at the alkaline surface of the cell (Mcconnaughey and others 1994). The benthic fraction of primary production for these two lakes is $46 \%$ for Mullutu Suurlaht and 94\% for Äntu Sinijärv (Table 2) (Cremona and others 2016). In these two lakes, correcting the $\alpha$ values for the BF of primary production increased the fit between observed and expected slopes (Figure 5C). This suggests that benthic calcification by macrophytes can be equally or more important than pelagic calcite precipitation in driving changes in $\mathrm{dDIC} / \mathrm{dt}$ in lakes that have a high fraction of primary production of benthic origin, and highlights the need to be spatially inclusive and include all metabolic components (benthic and pelagic) when addressing ecosystem-scale DIC dynamics (Obrador and Pretus 2013). This is especially relevant in shallow oligotrophic systems where benthic charophytes can reach similar production rates as pelagic phytoplankton communities under highly eutrophic conditions (Christensen and others 2013). 
Besides calcite precipitation, other factors may lead to deviations from the metabolic slope of -1 , such as physical processes or anaerobic respiration. However, any physical effects such as gas exchanges, water movements, or external inputs of DIC due to storm events can be discarded because the metabolic diel signals were isolated from any non-metabolic signal. As for anaerobic respiration, the vertical distributions of temperature, DO and $\mathrm{CO}_{2}$ presented in Laas and others (2016) for each lake during the same measurement period as this study, suggest that anaerobic processes have no major effect on surface waters at the measuring depths that were used for this study, especially considering the absence or very weak presence of gradient in $\mathrm{CO}_{2}$ concentrations in the surface water layer. Two strong evidences suggest that calcite precipitation is the main mechanism causing these deviations: firstly, the observed slopes are strongly correlated with the expected slopes under calcite precipitation conditions, and secondly, the degree of deviation from the metabolic slope is positively correlated with lake alkalinity. Several other studies in other aquatic systems have suggested that calcite precipitation/dissolution is responsible for such deviations due to the $\mathrm{CO}_{2}$ release/consumption (Gattuso and others 1999; Barrón and others 2006; Obrador and Pretus 2013).

Recent evidence suggests that in lakes of high alkalinity, large pools of DIC support higher rates of primary production, whereas in lakes of low alkalinity, primary production can be strongly DIClimited (Kragh and Sand-Jensen 2018). Considering the coupling between primary production and calcite precipitation, it is likely that high production in lakes of high alkalinity during summer production peaks results in high rates of calcite precipitation that compensates photosynthetic DIC depletion by releasing $\mathrm{CO}_{2}$. However, this mechanism is likely irrelevant in low alkalinity lakes, where DIC limitation minimizes primary production and calcite precipitation.

This study focuses on inorganic carbon dynamics within the aquatic systems without directly addressing questions related to $\mathrm{CO}_{2}$ emissions to the atmosphere. An interesting addition to this work would be to relate the observed and expected sensitivity of DIC to metabolic changes in DO, to $\mathrm{CO}_{2}$ emissions. Even though there is a net loss of $1 \mathrm{~mol}$ of DIC per mole of calcite that precipitates, the process of calcification is acknowledged to increase $\mathrm{CO}_{2}$ supersaturation in surface waters because it also releases $1 \mathrm{~mol}$ of $\mathrm{CO}_{2}$, thereby acting as a carbon source to the atmosphere (Opdyke and Walker 1992; Frankignoulle and others 1995; Su- zuki 1998). Considering that DIC dynamics are largely driven by calcite precipitation in lakes of high alkalinity, this process is likely to be an important driver of $\mathrm{CO}_{2}$ supersaturation in these lakes. Marcé and others (2015) suggested a threshold of 1 meq $\mathrm{L}^{-1}$ above which metabolism alone is not enough in explaining DIC dynamics. This threshold seems consistent with our results (Figure 5), but only one lake at alkalinity lower than 1 meq $L^{-1}$ is represented in this study and therefore we cannot clearly identify and confirm this threshold. Marcé and others (2015) further suggested that $57 \%$ and $34 \%$ of the global area occupied by lakes have alkalinity values above 1 meq $\mathrm{L}^{-1}$ and 2 meq $\mathrm{L}^{-1}$, respectively, which implies an important global contribution of calcite precipitation to $\mathrm{CO}_{2}$ supersaturation in lakes. Our results agree well with this statement, as all of the lakes above 1 meq $\mathrm{L}^{-1}$ (7 out of 8 lakes) show clear deviations from the -1 metabolic slope, with a tendency of stronger deviations at higher alkalinity (Figure 5B and C). Therefore, calcite precipitation may have a major contribution in global atmospheric $\mathrm{CO}_{2}$ emissions from surface waters.

\section{Numerical Considerations}

The periodograms for DO and DIC showed a large number of signals with oscillations at shorter time periods than the 24-h metabolic diel signal (Figures 1 and 2), but the spectrum was so weak that it seemed of minor importance. However, when calculating rates of change from the raw DO and DIC data, these signals at shorter period were amplified to the extent where the diel signal became hidden in shorter oscillations of high amplitude (Supplementary Figures S1 and S2). These short time period signals cannot be explained by the metabolic balance between photosynthesis and respiration and are caused by non-metabolic processes. All the studied lakes have a large amount of noise in their DO and DIC data resulting from the high frequency in measurements that capture noisy random signals, and imprecisions in the $\mathrm{pH}$ sensors that create substantial errors when calculating DIC values due to the exponential scale of $\mathrm{pH}$. Other physical processes may also cause the random short time period signals observed in these lakes, such as atmospheric or internal gas exchanges (Wissel and others 2008; Antenucci and others 2013), as well as water movements caused by convection, turbulence, minor mixing events or seiches. The crosswavelets for DO and DIC reveal that significant oscillatory signals are commonly found between 1and 8 -h frequency. This cannot be classified as 
noise and needs to be linked to internal processes of the lakes. One explanation could be found in the seasonal pattern of internal seiches which corresponds well to the 1 - to 8 -h frequency in oscillation (Bernhardt and Kirillin 2013). Despite the amount of noise and non-metabolic signals, the cross-wavelets revealed a clear anti-phase coupling between DO and DIC around the 24-h period in most of the lakes, which is to be expected if aerobic metabolism is the main driver of both DO and DIC dynamics (Figure 3). In some lakes, this coupling was weak or interrupted, especially in Äntu Sinijärv where it was almost totally absent due to the particularities of this lake (DIC dynamics are mostly driven by groundwater DIC-rich inputs).

Despite the amount of noise and sometimes weak diel signals, Singular Spectrum Analysis is an efficient tool that allowed us to enhance the metabolic diel signal-to-noise ratio, by isolating and extracting the diel signals for DO and DIC. In contrast to a smoothing function which would smooth out the noisy signals without getting rid of them, SSA identifies the fundamental oscillations within a time series. Therefore, the diel signals that are isolated using this tool are not affected by unwanted signals such as noise or non-metabolic processes.

\section{Conclusions}

- Calcite precipitation is an important process in driving carbon dynamics in lakes of high alkalinity, which represents more than half of the global area occupied by lakes and reservoirs. Acknowledged to act as a carbon source to the atmosphere, it is likely that calcite precipitation is an important driver of $\mathrm{CO}_{2}$ fluxes in lakes globally.

- The importance of calcification in driving carbon dynamics can be assessed using an alkalinitydependent parameter $(\alpha)$. In lakes that have a high benthic fraction of primary production, $\alpha$ must be corrected to account for calcification by macrophytes.

- Considering diurnal changes in alkalinity is mandatory for precise estimations of DIC concentrations and dynamics.

- The problem of noisy high-frequency measurements datasets can be effectively overcome using Singular Spectrum Analysis to enhance the signal-to-noise ratio by extracting the signal of interest, such as diel signals.

\section{ACKNOWLEDGEMENTS}

This study was funded by MANTEL ITN (Management of climatic extreme events in lakes and reservoirs for the protection of ecosystem services) through European Union's Horizon 2020 research and innovation program under the Marie Skłodowska-Curie Grant Agreement No 722518, by Estonian Ministry of Education and Research (IUT 21-02), by the Estonian Research Council grant (PUT PSG32) and by the project C-HYDROCHANGE (CGL2017-86788-C3-3-P and CGL201786788-C3-2-P) funded by the Spanish Ministry of Science, Innovation and Universities.

\section{OPEN ACCESS}

This article is licensed under a Creative Commons Attribution 4.0 International License, which permits use, sharing, adaptation, distribution and reproduction in any medium or format, as long as you give appropriate credit to the original author(s) and the source, provide a link to the Creative Commons licence, and indicate if changes were made. The images or other third party material in this article are included in the article's Creative Commons licence, unless indicated otherwise in a credit line to the material. If material is not included in the article's Creative Commons licence and your intended use is not permitted by statutory regulation or exceeds the permitted use, you will need to obtain permission directly from the copyright holder. To view a copy of this licence, visit $h$ ttp://creativecommons.org/licenses/by/4.0/.

DATA AVAILABILITY

Data are available at: https://doi.org/10.6073/past a/421c3435f2a735fe472511fda4ed5e5f.

Code information is available at: https://doi.org/10. 5281 /zenodo.3465312.

\section{REFERENCES}

Andersen RM, Kragh T, Martinsen T, Kristensen E, Sand-Jensen K. 2019. The carbon pump supports high primary production in a shallow lake. Aquat Sci 81:24. https://doi.org/10.1007/ s00027-019-0622-7.

Antenucci JP, Tan KM, Eikaas HS, Imberger J. 2013. The importance of transport processes and spatial gradients on in situ estimates of lake metabolism. Hydrobiologia 700:9-21.

Barrón C, Duarte CM, Frankignoulle M, Borges AV. 2006. Organic carbon metabolism and carbonate dynamics in a Mediterranean seagrass (Posidonia oceanica) meadow. Estuaries and Coasts 29:417-26. https://doi.org/10.1007/BF02784990.

Battin TJ, Luyssaert S, Kaplan LA, Aufdenkampe AK, Richter A, Tranvik LJ. 2009. The boundless carbon cycle. Nat Geosci 2:598-600. https://doi.org/10.1038/ngeo618. 
Berggren M, Lapierre J-F, del Giorgio PA. 2011. Magnitude and regulation of bacterioplankton respiratory quotient across freshwater environmental gradients. ISME J 6:984-93.

Bernhardt J, Kirillin G. 2013. Seasonal pattern of rotation-affected internal seiches in a small temperate lake. Limnol Oceanogr 58:1344-60. https://doi.org/10.4319/lo.2013.58.4. 1344.

Caspers H. 1984. OECD: Eutrophication of waters. Monitoring, assessment and control. - $154 \mathrm{pp}$. Paris: Organisation for Economic Co-Operation and Development 1982. (Publié en français sous le titre Eutrophication des Eaux. Méthodes de Surveillance, d'Evaluation et de Lutt. Int Rev der gesamten Hydrobiol und Hydrogr 69:200. https://onlinelibrary.wiley.c om/doi/abs/10.1002/iroh.19840690206.

Chan K-S, Ripley B. 2018. Time series analysis TSA. https://cran. r-project.org/web/packages/TSA/.

Christensen JPA, Sand-jensen KAJ, Staehr PA. 2013. Fluctuating water levels control water chemistry and metabolism of a charophyte-dominated pond. Freshw Biol 58:1353-65.

Cole JJ, Prairie YT, Caraco NF, McDowell WH, Tranvik LJ, Striegl RG, Duarte CM, Kortelainen P, Downing JA, Middelburg JJ, Melack J. 2007. Plumbing the global carbon cycle: integrating inland waters into the terrestrial carbon budget. Ecosystems 10:171-84. https://doi.org/10.1007/s10021-006-9013-8.

Cremona F, Laas A, Arvola L, Pierson D, Nõges P, Nõges T. 2016. Numerical exploration of the planktonic to benthic primary production ratios in lakes of the baltic sea catchment. Ecosystems 19:1386-400. https://doi.org/10.1007/s10021-01 6-0006-y.

Del Giorgio PA, Cole JJ, Caraco NF, Peters RH. 1999. Linking planktonic biomass and metabolism to net gas fluxes in northern temperate lakes. Ecology 80:1422-31.

Dittrich M, Obst M. 2004. Are picoplankton responsible for calcite precipitation in lakes? Ambio 33:559-64. https://doi. org/10.1579/0044-7447-33.8.559.

Duarte CM, Prairie YT. 2005. Prevalence of heterotrophy and atmospheric $\mathrm{CO}_{2}$ emissions from aquatic ecosystems. Ecosystems 8:862-70. https://doi.org/10.1007/s10021-005-0177-4.

European Union. 2000. Directive 2000/60/EC of the European Parliament and of the council. In: Vol. 327.

Frankignoulle M, Canon C, Gattuso J-P. 1994. Marine calcification as a source of carbon dioxide: positive feedback of increasing atmospheric $\mathrm{CO}_{2}$. Limnol Oceanogr 39:458-62. h ttps://doi.org/10.4319/lo.1994.39.2.0458.

Frankignoulle M, Pichon M, Gattuso J-P. 1995. Aquatic calcification as a source of carbon dioxide. Carbon Sequestration Biosph 33:265-71. https://doi.org/10.1007/978-3-642-799433_18.

Gattuso J-P, Frankignoulle M, Smith SV. 1999. Measurement of community metabolism and significance in the coral reef $\mathrm{CO}_{2}$ source-sink debate. Proc Natl Acad Sci 96:13017-22. https://d oi.org/10.1073/pnas.96.23.13017.

Gattuso J-P, Frankignoulle M, Smith SV, Ware JR, Wollast R, Buddemeier RW, Kayanne H. 1996. Coral reefs and carbon dioxide. Science 271:1298-300.

Gattuso J-P, Pichon M, Delesalle B, Frankignoulle M. 1993. Community metabolism and air-sea $\mathrm{CO}_{2}$ fluxes in a coral-reef ecosystem (Moorea, French-Polynesia). Mar Ecol Ser 96:25967.

Golyandina N, Korobeynikov A. 2014. Basic singular spectrum analysis and forecasting with R. Comput Stat Data Anal 71:934-54. https://doi.org/10.1016/j.csda.2013.04.009.
Gouhier TC, Grinsted A, Simko V. 2015. Biwavelet: conduct univariate and bivariate wavelet analyses. http://github.com/ tgouhier/biwavelet.

Grinsted A, Moore JC, Jevrejeva S. 2004. Application of the cross wavelet transform and wavelet coherence to geophysical time series. Nonlinear Process Geophys 11:561-6. https://doi.org/ 10.5194/npg-11-561-2004.

Hanson PC, Carpenter SR, Armstrong DE, Stanley EH, Kratz TK. 2006. Lake dissolved inorganic carbon and dissolved oxygen: changing drivers from days to decades. Ecol Monogr 76:34363.

Jonsson A, Karlsson J, Jansson M. 2003. Sources of carbon dioxide supersaturation in clearwater and humic lakes in northern Sweden. Ecosystems 6:224-35.

Khan H. 2019. Singular spectrum analysis using rSSA package. $\mathrm{h}$ ttps://doi.org/10.5281/zenodo.3465312.

Kragh T, Sand-Jensen K. 2018. Carbon limitation of lake productivity. Proc R Soc B Biol Sci 285:20181415.

Laas A, Cremona F, Meinson P, Rõõm E-I, Nõges T, Nõges P. 2016. Summer depth distribution profiles of dissolved $\mathrm{CO}_{2}$ and $\mathrm{O}_{2}$ in shallow temperate lakes reveal trophic state and lake type specific differences. Sci Total Environ 566-567:6375. https://doi.org/10.1016/j.scitotenv.2016.05.038.

Laas A, Khan H. 2019. Short-term high-frequency water dissolved carbon dioxide, temperature, dissolved oxygen, salinity and $\mathrm{pH}$ data from 8 Estonian lakes in year 2014. Environmental Data Initiative. https://doi.org/10.6073/pasta/421c34 35f2a735fe472511fda4ed5e 5f.

Larsen S, Andersen T, Hessen DO. 2011. The $\mathrm{pCO}_{2}$ in boreal lakes: organic carbon as a universal predictor? Global Biogeochem Cycles . https://doi.org/10.1029/2010GB003864.

Lewis E, Wallace D, Allison LJ. 1998. Program developed for CO2 system calculations. Carbon Dioxide Inf Anal Cent: 1-21. http://cdiac.esd.ornl.gov/oceans/co2rprtnbk.html.

López P, Marcé R, Armengol J. 2011. Net heterotrophy and $\mathrm{CO}_{2}$ evasion from a productive calcareous reservoir: adding complexity to the metabolism- $\mathrm{CO}_{2}$ evasion issue. J Geophys Res Biogeosciences 116:1-14.

Maberly SC, Barker PA, Stott AW, De Ville MM. 2012. Catchment productivity controls $\mathrm{CO}_{2}$ emissions from lakes. Nat Clim Chang 3:391-4.

Marcé R, Obrador B, Morguí Josep-Anton, Riera JL, López P, Joan A. 2015. Carbonate weathering as a driver of CO2 supersaturation in lakes. Nat Geosci 8:107-11.

McConnaughey T. 1991. Calcification in Chara corallina: $\mathrm{CO}_{2}$ hydroxylation generates protons for bicarbonate assimilation. Limnol Oceanogr 36:619-28. https://doi.org/10.4319/lo.1991. 36.4.0619.

Mcconnaughey TA, Labaugh JW, Rosenberry DO, Striegel RG, Reddy MM, Schuster PF, Carter V. 1994. Carbon budget for a groundwater-fed lake: calcification supports photosynthesis. Limnol Oceanogr 39:1319-32. https://doi.org/10.4319/lo.199 4.39.6.1319.

McConnaughey TA, Whelan JF. 1997. Calcification generates protons for nutrient and bicarbonate uptake. Earth Sci Rev 42:95-117. https://doi.org/10.1016/S0012-8252(96)00036-0.

McDonald CP, Stets EG, Striegl RG, Butman D. 2013. Inorganic carbon loading as a primary driver of dissolved carbon dioxide concentrations in the lakes and reservoirs of the contiguous United States. Global Biogeochem Cycles 27:285-95. https://d oi.org/10.1002/gbc.20032. 
Megard RO. 1968. Planktonic photosynthesis and the environment of carbonate deposition in lakes. SIL Commun 19531996(17):94. https://doi.org/10.1080/05384680.1969.119038 73.

Millero FJ. 1979. The thermodynamics of the carbonate system in seawater. Geochim Cosmochim Acta 43:1651-61. https://d oi.org/10.1016/0016-7037(79)90184-4.

Minder-Zürich L. 1922. Über biogene Entkalkung im Zürichsee. SIL Proceedings 1922-2010(1):20-32. https://doi.org/10.108 $0 / 03680770.1923 .11896446$.

Ministry of the Environment. 2009. Procedure for the establishment of bodies of surface water and a list of the bodies of surface water the state of which is to be established, classes of the states and the values of quality indicators corresponding to these state classes, and the procedure. Minist Environ 11. W ww.riigiteataja.ee/akt/13210253.

Müller B, Meyer JS, Gächter R. 2016. Alkalinity regulation in calcium carbonate-buffered lakes. Limnol Oceanogr 61:34152. https://doi.org/10.1002/lno.10213.

Nõges P, Cremona F, Laas A, Martma T, Rõõm EI, Toming K, Viik M, Vilbaste S, Nõges T. 2016. Role of a productive lake in carbon sequestration within a calcareous catchment. Sci Total Environ 550:225-30

Obrador B, Pretus JL. 2013. Carbon and oxygen metabolism in a densely vegetated lagoon: implications of spatial heterogeneity. Limnetica 32:321-36.

Obst M, Wehrli B, Dittrich M. 2009. $\mathrm{CaCO}_{3}$ nucleation by cyanobacteria: laboratory evidence for a passive, surface-induced mechanism. Geobiology 7:324-47. https://doi.org/10. $1111 / j .1472-4669.2009 .00200 . x$.

Opdyke BN, Walker JCG. 1992. Return of the coral reef hypothesis: basin to shelf partitioning of $\mathrm{CaCO}_{3}$ and its effect on atmospheric $\mathrm{CO}_{2}$. Geology 20:733-6.

Peeters F, Atamanchuk D, Tengberg A, Encinas-Fernández J, Hofmann H. 2016. Lake metabolism: comparison of lake metabolic rates estimated from a diel $\mathrm{CO}_{2}$-and the common diel $\mathrm{O}_{2}$-Technique. PLoS ONE 11:1-24. https://doi.org/10.13 71/journal.pone.0168393.

Perga M-E, Maberly SC, Jenny J-P, Alric B, Pignol C, Naffrechoux E. 2016. A century of human-driven changes in the carbon dioxide concentration of lakes. Glob Biogeochem Cycles 30:93-104. https://doi.org/10.1002/2015GB005286.

R Development Core Team. 2015. R: a language and environment for statistical computing. http://www.r-project.org/.

Riebesell U, Zondervan I, Rost B, Tortell PD, Zeebe RE, Morel FMM. 2000. Reduced calcification of marine plankton in response to increased atmospheric CO2. Nature 407:364-7. h ttps://doi.org/10.1038/35030078.

Roehm CL, Prairie YT, Del Giorgio PA. 2009. The $\mathrm{pCO}_{2}$ dynamics in lakes in the boreal region of northern Quebec, Canada. Glob Biogeochem Cycles 23:1-9. https://doi.org/10.1029/200 8 GB003297.

Rõõm EI, Nõges P, Feldmann T, Tuvikene L, Kisand A, Teearu H, Nõges T. 2014. Years are not brothers: two-year comparison of greenhouse gas fluxes in large shallow Lake Võrtsjärv, Esto- nia. J Hydrol 519:1594-606. https://doi.org/10.1016/j.jhydrol. 2014.09.011.

Sand-jensen K, Staehr PA. 2009. Net heterotrophy in small Danish lakes: a widespread feature over gradients in trophic status and land cover. Ecosystems 12:336-48.

Sobek S, Tranvik LJ, Cole JJ. 2005. Temperature independence of carbon dioxide supersaturation in global lakes. Glob Biogeochem Cycles 19:1-10. https://doi.org/10.1029/2004G B002264.

Stabel H-H. 1986. Calcite precipitation in lake constance: chemical equilibrium, sedimentation, and nucleation by algae. Limnol Oceanogr 31:1081-93. https://doi.org/10.4319/lo. 1986.31.5.1081.

Stets EG, Striegl RG, Aiken GR, Rosenberry DO, Winter TC. 2009. Hydrologic support of carbon dioxide flux revealed by whole-lake carbon budgets. J Geophys Res 114:1-14. https://d oi.org/10.1029/2008JG000783.

Stumm W, Morgan JJ. 1996. Aquatic chemistry: chemical equilibria and rates in natural waters. 3rd edn. New York: Wiley.

Suzuki A. 1998. Combined effects of photosynthesis and calcification on the partial pressure of carbon dioxide in seawater. J Oceanogr 54:1-7. https://doi.org/10.1007/BF02744376.

Torgersen T, Branco B. 2007. Carbon and oxygen dynamics of shallow aquatic systems: process vectors and bacterial productivity. J Geophys Res Biogeosci 112:1-16. https://doi.org/ 10.1029/2007JG000401.

Tranvik LJ, Downing JA, Cotner JB, Loiselle SA, Striegl RG, Ballatore TJ, Dillon P, Finlay K, Fortino K, Knoll LB, Kortelainen PL, Kutser T, Larsen S, Laurion I, Leech DM, McCallister SL, McKnight DM, Melack JM, Overholt E, Porter JA, Prairie Y, Renwick WH, Roland F, Sherman BS, Schindler DW, Sobek S, Tremblay A, Vanni MJ, Verschoor AM, von Wachenfeldt E, Weyhenmeyer GA. 2009. Lakes and reservoirs as regulators of carbon cycling and climate. Limnol Oceanogr 54:2298-314. https://doi.org/10.4319/lo.2009.54.6_part_2.22 98.

Vachon D, del Giorgio PA. 2014. Whole-lake $\mathrm{CO}_{2}$ dynamics in response to storm events in two morphologically different lakes. Ecosystems 17:1338-53. https://doi.org/10.1007/s1002 1-014-9799-8.

Weyhenmeyer GA, Kosten S, Wallin MB, Tranvik LJ, Jeppesen E, Roland F. 2015. Significant fraction of $\mathrm{CO} 2$ emissions from boreal lakes derived from hydrologic inorganic carbon inputs. Nat Geosci 8:933-6.

Wilkinson GM, Buelo CD, Cole JJ, Pace ML. 2016. Exogenously produced $\mathrm{CO}_{2}$ doubles the $\mathrm{CO}_{2}$ efflux from three north temperate lakes. Geophys Res Lett 43:1996-2003. https://doi.org/ 10.1002/2016GL067732.

Wissel B, Zoraida JQ-R, Fry B. 2008. Combined analyses of $\mathrm{O}_{2}$ and $\mathrm{CO}_{2}$ for studying the coupling of photosynthesis and respiration in aquatic systems. Can J Fish Aquat Sci 65:237888. https://doi.org/10.1139/F08-146.

Zhao D. 2016. SSA: simultaneous signal analysis. https://cran.rproject.org/web/packages/ssa/index.html. 